Vol. 16, n² | 2012

Varia

\title{
Summary Justice for Women : Stafford Borough, 1880-1905
}

Joanne Turner

\section{(2) OpenEdition \\ Journals}

Electronic version

URL: http://journals.openedition.org/chs/1359

DOI: 10.4000/chs.1359

ISSN: 1663-4837

Publisher

Librairie Droz

Printed version

Date of publication: 1 December 2012

Number of pages: $55-77$

ISBN: 978-2-600-01642-1

ISSN: 1422-0857

\section{Electronic reference}

Joanne Turner, «Summary Justice for Women : Stafford Borough, 1880-1905 », Crime, Histoire \& Sociétés / Crime, History \& Societies [Online], Vol. 16, n² | 2012, Online since 01 December 2015, connection on 10 December 2020. URL : http://journals.openedition.org/chs/1359 ; DOI : https:// doi.org/10.4000/chs.1359 


\title{
Summary Justice for Women: Stafford Borough, 1880-1905
}

\author{
Joanne Turner ${ }^{1}$
}

\begin{abstract}
Bien que les femmes ayant commis des infractions graves et les prostituées étaient des marginales à leur époque, elles ont fait l'objet d'une quantité disproportionnée de recherches universitaires. Au contraire, quoique toujours en situation d'infériorité par rapport aux hommes délinquants, les petites délinquantes femmes étaient plus nombreuses que les précédentes, mais largement ignorées des historiens et des criminologues, en particulier lorsqu'elles vivaient et agissaient en dehors de la métropole. Prenant le cas de la ville marchande à dominante ouvrière de Stafford, cet article cherche à réduire ce déséquilibre en décrivant la participation des femmes à une criminalité banale et moins ouvertement genrée, à la fin du XIX ${ }^{e}$ siècle. Il montre par là qu'il y avait relativement peu de délinquants juvéniles mais de nombreuses femmes d'âge moyen, condamnées principalement pour ivresse ou désordres, coups et blessures, et violation de réglementations de plus en plus présentes.
\end{abstract}

Serious female offenders and prostitutes were marginal individuals in their own time, yet both have received a disproportionate amount of scholarly research. Although still overshadowed by male offenders of any type, the female petty offender was more prevalent. Yet such common-place female offenders have been largely ignored by historians and criminologists, particularly those living and offending outside the Metropolis. By using a largely working-class market town as a case study, this article aims to redress that imbalance by establishing the participation of women in mundane and less overtly gendered crime in late nineteenth century Stafford. In so doing, the article will show that there were comparatively few juvenile offenders and a host of middleaged women mainly convicted for drunken and anti-social behaviour, common assault, and breaching the increasing regulatory legislation.

Wistorians and criminologists have observed that women commit much less crime than men and, when they do offend, they tend not to commit serious offences. However, although there is now a considerable body of scholarly work on

1 Dr Jo Turner recently defended her doctoral thesis from Keele University (UK) on female offending, punishment and reform in Stafford between 1880 and 1905 . Her first publication is: 'Punishing Women, 1880-1905', Howard Journal of Criminal Justice, 2011, 50, 5, pp. 505-515. She has been involved with various research projects and is currently working with Professor Barry Godfrey, Dr Helen Johnston and Dr David Cox on an ESRC funded project researching the Costs of Imprisonment, 1853 to 1945. 
female offending, there remains a lack of knowledge about women's petty offending in the past, particularly where the late nineteenth century England is concerned. Statistical knowledge is particularly lacking. Indeed, as Kermode and Walker argued in their landmark work, there has been a tendency to duly count and then discount female offenders, except for such crimes as, for example, murder or prostitution, and this statement remains true today ${ }^{2}$. Scholarly understandings of women who offend in an historical context consequently remain firmly tied to those involving serious or sex-specific crimes. Little is known about female petty offenders, although women were more likely to be prosecuted for this type of offence. Even less is known about what crimes they committed, who prosecuted them and with what result, or how the women were subsequently treated by the criminal justice system. Any attempt to map the type and extent of female crime must fully engage with women's petty offending. In so doing, the mundane and non sex-specific nature of women's offending becomes clear.

To expand scholarly knowledge of female offending in the past, this article analyses data relating to all events for which women were prosecuted before the Stafford Borough Petty Sessions (including those committed to the Quarter Sessions and Assizes) from 1 January 1880 to 31 December $1905^{3}$. The analysis shows unequivocally that female offending in Stafford was indeed principally a matter for the Petty Sessions.

The Petty Sessions issued 2,869 summonses over this period. Except for 147 cases which were either absconded or settled out of court, only fifty-three cases were committed to a court higher than the Petty Sessions. Even though their administrative functions were whittled away and finally abolished by the 1888 Local Government Act, there was a significant expansion of summary jurisdiction throughout the nineteenth century and by the 1880s key legislation had altered the nature of local justice ${ }^{4}$. However, within England's formal legal process, the court of summary justice remained the first port of call for those committed for trial and hence continued to be the gatekeeper of criminal justice. Stafford's magistrates' court processed all cases against women who were accused of offending in Stafford between 1880 and 1905 and dealt with 98 percent of such cases from start to finish.

To date, crime historians have either taken a general sweep and examined female criminality and women's subsequent treatment by the criminal justice system over a long period ${ }^{5}$, or they have restricted their work on women who offended during the late nineteenth and early twentieth centuries to cases where women were accused of crimes that were specifically associated with women at the time, such as baby farming and infanticide ${ }^{6}$. Most research has focused particularly on cases where women were tried before the higher courts or were sentenced to death, often seeking to explain the decline of women prosecuted at the higher courts between

Kermode, Walker (1994, p. 4).

Hereafter referred to as 'Stafford'. Stafford County had its own Petty Sessions.

For a discussion of this legislation see, inter alia, Gatrell (1980, pp. 302-303) ; Conley (1991, pp. 17 18 \& 160-161); Emsley (1996, pp. 159-161); Taylor (1998, p. 18).

For example Zedner (1991); D’Cruze, Jackson (2009).

6 Behlmer (1979); Hoffer, Hull (1981); Rose (1986); Higginbotham (1989); Arnot (1994a, 1994b); Ward (1999); Jackson (2002), Grey (2009). 
the late seventeenth and early twentieth centuries ${ }^{7}$. Either way, much work has been concentrated in the Metropolis and other large cities, chiefly those in the northwest of England. This focus on trials against women in the higher courts has overshadowed other significant but mundane categories of female offending such as common assault, theft and drunkenness that were dealt with in a court of summary justice. Only prostitutes have received considerable attention within historical scholarship, particularly with reference to the Contagious Diseases Acts of the 1860 s to $1880 \mathrm{~s}^{8}$. Although prostitution was a prominent form of female deviance during the nineteenth century, the importance attached to the prostitute has obscured the large numbers of women that came before the magistrates in the Petty Sessions accused of crimes such as drunkenness and common assault, which collectively accounted for far more female convictions than prostitution during the second half of the nineteenth century ${ }^{9}$.

Recently crime historians have recognised this imbalance and have begun to explore women's petty offending in greater depth. For example, there is now a large body of exemplary work on female offending in late-eighteenth and early-nineteenth century London, which examines the involvement of women for mundane offences such as theft, interpersonal violence, pick-pocketing, and shop-lifting ${ }^{10}$. During this earlier period, such offences would probably have been tried in a higher court rather than the Petty Sessions. However, there is also a growing body of work on female petty offending during late nineteenth and early twentieth centuries. For example, D'Cruze has examined 'everyday' violence committed by women; Morrison has examined how and why drunken women were constructed as a prominent social problem; and Whitlock has charted the increase of retail crimes, such as shoplifting, which were largely perpetrated by women ${ }^{11}$. This substantial body of work has undeniably provided valuable insights into the types of crime that women were accused of committing and their subsequent treatment by the criminal justice system. However, there remains a gap in knowledge about female offending in general, particularly offending of a mundane nature, which took place outside London and the heavily industrialised cities of the Northwest at the turn of the last century.

Located midway between the Potteries to the north and the Black Country to the south, Stafford is the county town of Staffordshire. Through boundary changes, a rise in population and migration of people looking for work within the town's shoe and boot industry, the spatial area of Stafford grew over the second half of the nineteenth century. Similarly its population grew from 9,904 in 1841 to 25,000 in $1901^{12}$. It was not, therefore, a significant metropolis during the period under

\footnotetext{
Ballinger (2000); Feeley, Little (1991). Notable exceptions are King (1996); Godfrey (2004, 2007).

8 Finnegan (1979); Walkowitz (1980); Bartley (2000).

9 Zedner (1991, pp. 34-35).

10 For example, MacKay (1999); Palk (2006); Gray (2007); D'Cruze, Jackson (2009). See also Grace (1998). This work, however, looks at summary justice for women in York and Hull prior to 1870 rather than London.

11 D'Cruze (2000); Morrison (2005); Whitlock (2005).

12 This was much in line with the overall trend for England and Wales. The process of urbanisation in England and Wales was, of course, slow and uneven. However it is significant that at the turn of the twentieth century, 686 (11.4 percent) of towns had a population of less than 10,000, while approximately one quarter of all urban dwellers lived in towns, like Stafford, populated by between 10,000 and 50,000 inhabitants. See Waller (1991, p. 6).
} 
investigation. However, it was important enough to have small militia barracks, a large county gaol, two asylums, a workhouse and a hospital, and was the market and transport centre for its prosperous farming hinterland. Stafford's main industry was boot and shoe making and by 1881 the trade employed 15 percent of the entire population of the town ${ }^{13}$.

Thirteenth century Stafford was important enough to attract the Franciscans, or Grey Friars, to the town. Their friary was built north of the settlement in $1274-$ hence the name of the main road (Greyfriars) into the town from the north. Barely a trace remains of the medieval walls and gates, but the layout is still reflected in its street names - North and South Walls, and Greengate, Eastgate, Foregate and Gaolgate Streets. Foregate, the suburb to the north of the town, expanded through the nineteenth century, and took in Greyfriars. It contained most of the increasing shoe and boot factories, and housing to accommodate workers, as well as the prison. The area to the west, Broad Eye, was an increasingly populous area where Stafford Corporation built the first nine council houses in 1901. During the period under investigation, Broad Eye was the scene of many neighbourhood disputes involving women. It is hardly surprising that long-standing feuds or family antagonism could periodically flare up in these cramped, run down terraces, accommodating people who had known each other for a long time ${ }^{14}$. To the south, the town boundaries had been extended following the 1835 Municipal Corporations Act to include a small community called Forebridge where additional houses were built. The opening of the Grand Junction Railway in 1837, and a growing number of railway employees living in the town, led to the building of a whole new suburb close to the station known as Castletown.

Based on industry and manufacture, Stafford was fundamentally a working-class market town which, by the latter decades of the nineteenth century, had some fine buildings and good amenities although slums continued to characterise the older parts. Conditions were worst in such localities as Snow's Yard (a court off Greyfriars), Cherry Street, Duke Street, and Red Lion Street in the Broad Eye area, and the Back Walls North and South in the town centre. On a visit to Stafford in 1852, Charles Dickens was unimpressed with what he saw. Describing Stafford 'as dull and dead a town as anyone could desire not to see ${ }^{15}$, he emphasised how ordinary Stafford was. Stafford could, in fact, be seen as a microcosm of late nineteenth and early twentieth century working-class England. Therefore, whilst no claims are laid as to the typicality of the women offending in Stafford, and although no single town could ever stand for the whole, this article provides a detailed historical picture of female petty offending in a smaller, less urbanised provincial working-class town outside London and the heavily industrialised regions of England.

\section{FEMALE PROSECUTIONS IN STAFFORD}

There was a vast range of offences for which women in Stafford were charged. As can be seen from Chart 1, by far the largest category of offences was those associated with public order, which accounted for more than half of the cases.

\footnotetext{
13 Staffordshire Records Office (2007).

14 See Turner (2009 section 4:8) for a fuller discussion of the spatial dimension of women's offending.

15 Cited in Greenslade et al. (1995, p. 201).
} 


\section{Chart 1. Main Categories of Offence}

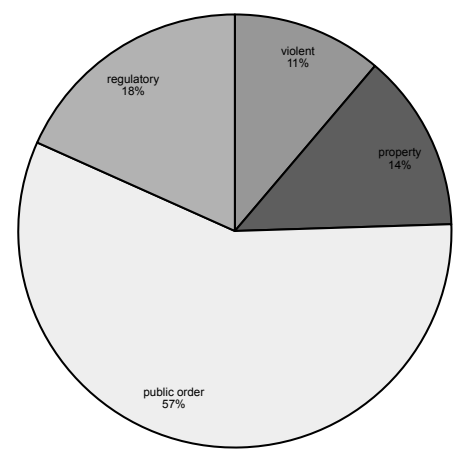

Within this large category of public order offenses, prosecutions for alcoholrelated offences, such as 'drunkenness' and 'being drunk and disorderly' accounted for over a third (36.2 percent) of all prosecutions. However, women only ever made up between a fifth and a third of the total number of people summonsed each year in Stafford for alcohol-related offences ${ }^{16}$. Thus women in Stafford were not disproportionately arrested for alcohol-related offences. Prosecutions for causing a 'nuisance', such as 'using obscene language', 'disturbing the peace' and 'annoying foot passengers', accounted for 14 percent of all prosecutions.

Table 1. Offence Sub-Categories

\begin{tabular}{|l|c|c|}
\hline Offence Categories & Frequency & Percent \\
\hline Pets and Livestock & 25 & 0.9 \\
\hline Attempted Suicide & 13 & 0.5 \\
\hline Burglary & 1 & 0.1 \\
\hline Drunkenness & 1039 & 36.2 \\
\hline Employment & 67 & 2.3 \\
\hline Family & 161 & 5.6 \\
\hline Licensing & 24 & 0.8 \\
\hline Nuisance & 402 & 14.0 \\
\hline Court Orders & 2 & 0.1 \\
\hline Property & 46 & 1.6 \\
\hline Prostitution & 91 & 3.2 \\
\hline Health & 229 & 8.0 \\
\hline
\end{tabular}

16 Figures taken from the 1888 licensing sessions at Stafford Petty Sessions. Staffordshire Advertiser (SA) 1 September 1888. The $S A$ was the main local newspaper and was published weekly, on Saturday. Each edition reported selected summary hearings from Stafford along with other towns in the county. 


\begin{tabular}{|l|c|c|}
\hline Theft & 334 & 11.6 \\
\hline Vagrancy & 110 & 3.8 \\
\hline Vehicular & 17 & 0.6 \\
\hline Violence & 308 & 10.7 \\
\hline Total & 2869 & 100.0 \\
\hline
\end{tabular}

During the latter decades of the nineteenth century, the criminal justice system in England considered habitual drunkenness to be a particular problem, and contending with it greatly strained the limited resources of the police and local magistrates' courts. However, during the period under investigation there was no legal definition of drunkenness. Under the 1872 Licensing Act, the police could arrest any person found drunk, or exhibiting riotous and disorderly behaviour while drunk, in a highway or other public place including licensed premises. Hence determining when a person was legally drunk necessarily relied heavily on police discretion. Moreover, the context in which women were arrested for such offences was not particularly gendered. That is, women drank in pubs and staggered their way home or had to be evicted from public houses by landlords (and sometimes the police) just as men were. In fact, many of the women in Stafford frequented their local public house with their men-folk. The police and magistrates in Stafford were not concerned about women's alcohol consumption per se, and even less about the impact of social conditions such as poverty, multiple births, and detrimental living conditions that probably underlay women's alcohol use. After all, the police themselves lived under similar conditions. It was the visibility of drunken women in the streets that concerned the police. Of the prosecutions for alcohol related offences in which there was a female defendant, all took place outdoors, except when the woman was also prosecuted for 'refusing to quit' licensed premises, and nearly half took place in the town centre. The police were particularly concerned to keep the main streets of Stafford free of the unsightly spectacle of drunken women, who may or may nor have been shouting abuse or causing fights, or annoying 'foot passengers' in this respectable part of Stafford.

As can be seen in Table 1 above, vagrancy and prostitution, whilst still considered public order offences, featured very marginally in the collection of offences together accounting for only 7 percent of the total number of prosecutions. Although prostitution was policed in very different ways in different places ${ }^{17}$, in Stafford it seems the police and magistrates were keen to keep the streets of Stafford clear of visible signs of immorality and destitution, rather than regulating prostitution per se. Prosecutions for prostitution, which included summonses for 'permitting' and 'soliciting', as well as 'prostitute behaving badly', accounted for just 3.2 percent of all cases. Prosecutions for vagrancy, which included summonses for 'sleeping out', 'having no visible means' and 'begging', accounted for just 3.8 percent of all prosecutions. In figures, there were only 91 cases relating to prostitution and 109 cases relating to vagrancy. The conviction rate for prostitution was high: out of the 91 cases, two were withdrawn and just two more produced a not-guilty verdict. Sentencing was equally unforgiving. Three-quarters of those found guilty were imprisoned. So although summonses for offences related to prostitution were

\footnotetext{
For a discussion on the regulation of prostitution in nineteenth century Britain see Howell (2009).
} 
relatively uncommon, when prosecuted the conviction rate was high and the sentence usually custodial.

However, women regarded by the police as prostitutes would also be prosecuted for other offences such as 'drunkenness' and 'stealing from the person' for example. Moreover, it was not unusual for the police and prison officers to record 'prostitute' as the occupation of those women they considered prostitutes even when the woman concerned was not being prosecuted for a prostitution-related offence. Likewise, the low number of prosecutions for vagrancy belies how many women the police and prison officers considered to be vagrants. Vagrant women were particularly likely to be prosecuted for drunkenness rather than 'begging' or 'sleeping out' but were recorded by the police as being vagrant with no fixed abode. Women considered to be prostitutes as well as those considered to be vagrant, once identified as being so by the police, continued throughout their offending history to be so classified even when they were never prosecuted for such offences thereafter. This was also true when 'prostitutes' subsequently married. Rather than being registered as 'married', they were categorised under the 'occupation' of 'prostitute' 18 .

In Stafford at the end of the nineteenth century, 'prostitutes' had not become the 'outcast group' described by Walkowitz ${ }^{19}$. There were only forty-seven women in Stafford who were ever convicted of prostitution between 1880 and 1905. All were convicted of other offences as well, usually public order offences but sometimes vagrancy or theft. Some were young and single 'prostitutes' who subsequently married; others were older and already married when first convicted. Some will have known each other; in fact three shared an address for a while and, on occasions, were together when arrested. For none of the 'prostitutes' of Stafford did their history seem to be an impediment to forming or maintaining a relationship. Rather, prostituting themselves seems to have been an option taken when in financial need. In fact, it seems that for some young, single women in Stafford prostitution was a way of earning money prior to marriage in the absence of regular employment. It did not lead to any of them specializing in 'prostitution', nor prevent them from forming or maintaining a relationship. For those 'prostitutes' who were married when convicted of prostitution, it was severe financial difficulties for the family that led them to prostitute themselves.

For example, Jane Biddulph was one of the young women convicted of prostitution who later went on to marry and have children. Jane was born in Stafford, as were her parents and siblings. She lived with them at a permanent address in Stafford throughout her childhood. However, twice she appeared in court as a single, young woman in response to summonses for prostitution - both times she was convicted and imprisoned. Aged twenty-four, and after having two children, Jane married William Gibbons. Two years after marrying, Jane was summonsed again for soliciting prostitution under her married name. When her husband found himself unable to support his family, Jane had turned to the only way she knew how to obtain money legitimately. In court, Jane testified in her defence that 'her husband had done no work for eighteen months ${ }^{20}$. This was to no avail, however, as Stafford magistrates imposed a ten-shilling fine, which neither Jane nor her family were able

\footnotetext{
18 See below for the occupations of the female defendants.

19 Walkowitz (1977).

20 SA, 23 November 1889.
} 
to pay. Consequently she was sent to prison again. Jane ceased to appear in court when her husband found employment in the boot and shoe trade.

Women were also summonsed for breaches of the welfare and health legislation that was increasing exponentially throughout the second half of the nineteenth century $^{21}$. By 1900 Stafford had a panoply of officials concerned with public health and employment, including an inspector for the National Society for the Prevention of Cruelty to Children (NSPCC), an inspector for the Royal Society for the Prevention of Cruelty to Animals (RSPCA), a Sanitary Inspector, a Markets Inspector, a School Attendance Officer, an Inspector of Nuisances, an Inspector of Weights and Measures, and a Medical Officer of Health. These types of offence accounted for 18.3 percent of all the cases and were largely summonsed by private and local authority agencies. Nevertheless, those receiving the summonses may have considered them police prosecutions, particularly when police officers took on roles such as 'inspector of lodging houses'. Women were generally not held accountable for many of these legislative breaches, such as ensuring their children went to school, when they had a male head of household. Many women, however, found themselves without a male head of household when widowed or separated from their husbands, which was the case for twenty-five women in the study. In a period with no state benefits, and women without a male breadwinner, separated and widowed, were forced to rely on their own employability and that of any children - and their dutifulness - or face destitution. Routinely, if these women were unable to meet the payments, a distress warrant would be issued.

Prosecution levels in Stafford did not remain constant. Across all offences there were between 63 summonses in 1903 and 179 in both 1892 and 1893 . However, when the number of summonses is juxtaposed against the population size, which was still rising during the research period, a gradual decline in the number of female summonses was apparent, although it is impossible to demonstrate whether this decline was a result of any actual reduction in violent or antisocial behaviour ${ }^{22}$. Yet there was a steady and real rise in women being brought before the magistrates accused of regulatory crimes, linked to the enactment of new legislation.

For example, before the passing of the 1889 Prevention of Cruelty to Children Act, women could be summonsed for cruelty to children under the Common Law, and after 1868, for neglect of children under the provisions of the 1868 Poor Law Amendment Act. Yet the only such cases in Stafford were three separate cases of 'causing a child to beg' between 1880 and 1889, and in all three cases the police were the complainants. However, with the appearance of the National Society for

$21 \quad$ Such as the Dogs Act (1871); the Intoxicating Liquors Act (1872); the Licensing Act (1874); the Public Health Act (1875); the Food and Drugs Act (1875); the Elementary Education Act (1876); the Cruelty to Animals Act (1876); the Weights and Measures Act (1889); and the Prevention of Cruelty to Children Act (1889).

22 Feeley and Little (1991) argue that the decline in indictable female crime reflects real changes in women's lives, particularly the separation of home and work and women's exclusion from the public sphere, leading to a decline in actual female criminality. The extent of these historical changes in women's lives has been questioned. King (2006) argues that the late nineteenth-century decline in the number of women prosecuted for indictable crime reflects the jurisdictional changes throughout the nineteenth century, as a large number of minor theft cases (which frequently involved women) were transferred to the lower courts. Nevertheless, in Stafford there was a real decrease in the number of women being brought before the magistrates in Stafford at the end of the nineteenth century for any type of offence. 
the Prevention of Cruelty to Children (NSPCC) in $1889^{23}$, female summonses in Stafford for 'neglect of children' grew exponentially. It made no difference whether the defendant lived in a male-headed household or not, yet the absolute number of such cases remained low. No women were accused of sexual abuse in Stafford, which is consistent with Jackson's findings for London where women featured as only 1 percent of defendants ${ }^{24}$. This is not to say that the offence did not take place in Stafford, rather that none were reported, detected or summonsed. Nevertheless, by 1891 an inspector for the Wolverhampton branch of the NSPCC was active in surveying and issuing summonses for neglect of children in Stafford, and by 1897 Stafford had its own inspector. 1891, therefore, saw the first female summons for 'neglect of children'. There was a peak in the next year with ten women summoned and thereafter the level was maintained at an average of three per year.

By and large, parents and guardians were summonsed and, if convicted, received the same penalty - invariably a prison sentence. Women summonsed for this offence generally did not have previous dealings with the court and were not subsequently summonsed unless for a similar offence. As far as Stafford magistrates were concerned, as long as the man could demonstrate that he provided financially for any children, he was considered to have fulfilled his responsibility for their care. In these cases, especially, the woman bore the impact of any conviction. In contrast to the treatment of women accused of infanticide ${ }^{25}$, summonses in Stafford for cases alleging 'neglect of children' had a very high conviction rate, and punishments were generally severe. In a period when women were carrying the chief burden of maintaining and developing a healthy British 'race' ${ }^{26}$, it is not surprising that adjudicators in Stafford were never lenient towards women proven to have neglected their children, regardless of the culpability of their partner: they were the ultimate 'bad' mothers, and therefore, 'bad' women.

As shown in Table 1 above, property offences accounted for 13 percent of all cases and included such offences as theft, 'receiving stolen goods', fraud, burglary and trespass. However, petty theft was by far the most common offence in this group. There were many cases of young domestic servants stealing from their employers, women stealing money either 'from the person' or by using 'false pretences', or stealing goods - such as a broom, sheets or beer from a pub - and stealing clothing and food. Theft of shoes and boots was particularly prominent as the manufacture and sale of such goods was Stafford's main industry. Finally, offences involving violence represented the smallest group of prosecutions accounting for 11 percent of all the prosecutions. Cases of common assault were very prevalent accounting for 10 percent of all the cases heard by Stafford magistrates in which there was a female

23 The society was originally founded as the London Society for the Prevention of Cruelty to Children in 1884. In 1889 it became the NSPCC, and set up a number a regional Aid Committees to deal with business outside London. For a more detailed discussion of the founding of the NSPCC see Behlmer (1982); Hendrick (1994). See also Turner (2009, section 6.5) for a more detailed discussion of the impact of the NSPCC in Stafford.

24 Jackson (2000).

25 See Grey (2009).

26 For a discussion of anxieties regarding infant mortality heightened by the Boer War 1899-1902 and working-class women's role in the wellbeing of the state, rather than just of individual families, see inter alia Morrison (2005, chapter 5); Zedner (1991, p. 13); Harrison (1990, pp. 102-142); Lewis (1980, pp. 15-18); Dyhouse (1978). 
defendant. Only 1 percent involved other forms of violence including attempted suicide, unlawful wounding, grievous bodily harm, throwing vitriol, concealment of birth, manslaughter and murder ${ }^{27}$. In the main, the women of Stafford fought over limited space in shared yards when putting their washing on the clothesline, in the street with neighbours over a misunderstood comment or money owed, or with their partner when fights originating in the home spilled out onto the street.

Women's offending in Stafford was indeed mundane in nature and reflected their limited opportunities for offending, and, like men, women were largely summonsed for drunken and anti-social behaviour, breaching increasing regulatory legislation, and common assault. This research collected the details of all women who appeared before Stafford magistrates. However, if summonses for public order offences and breaches of the welfare and health legislation, offences that some would not consider 'criminal' in the truest sense, are removed from the picture, only 702 out of the total 2,869 cases remain. Split between 321 violent offences and 381 property offences, these 702 cases average out at only twenty-seven cases per year. When further cases are removed in which women stole food or clothing, cases of common assault in which women had, for example, only thrown a bucket of water over her neighbour, and cases of attempted suicide, very few female prosecutions remained.

\section{PROSECUTING AGENCY AND CONVICTION RATES}

There were three principal ways in which a case could be brought to court. The first required the victim of an offence to issue a private summons against a defendant with or without police assistance. The second required a prosecuting agency, such as the NSPCC, to issue a summons and the third required the police to issue a summons on behalf of the victim, or in a 'victimless' crime such as drunkenness, on behalf of the public. Godfrey has demonstrated that the balance between these three was changing during the research period and that the police emerged as the main prosecuting body by the end of the Great $\mathrm{War}^{28}$. Legislative changes during the nineteenth century had made the prosecution of minor offenders in the Petty Sessions relatively cheap and easy ${ }^{29}$. The 1847 Juvenile Offender's Act granted magistrates the powers to try charges of simple larceny by juveniles aged less than fourteen years. This was raised to sixteen years in 1850. The 1879 Summary Jurisdiction Act widened the powers of magistrates to summarily try cases of theft and embezzlement that did not exceed twelve pounds. The 1885 Criminal Justice Act authorised magistrates to hear larceny cases where the value of the stolen goods did not exceed five shillings provided that the defendant(s) consented to a summary trial. In addition magistrates were permitted to hear larceny cases above five shillings in which the accused pleaded guilty. The Criminal Justice Act also transferred theft by servants from the higher courts to the Petty Sessions.

27 See Turner (2009 sections 4,11 and 4,12) for discussions of those cases committed to the Quarter Sessions and Assizes respectively. The twelve cases committed to the Assizes, the one alleged manslaughter and the two alleged murder cases each involved the woman's own child.

28 Godfrey (2008).

29 See note 4. 
Thus, up until the 1880s, the norm was for aggrieved individuals to accuse the suspected offender by obtaining a summons from the magistrate, and appear in court to prosecute the case, with or without the assistance of a solicitor. However, the increasing willingness by the police to act as prosecutors signalled the demise of private summonses issued by individuals. The Stafford's police and court records mention for each case who acted as complainant. Here the police were recorded as the complainant in 58.6 percent of all summonses involving a female defendant between 1880 and 1905, while the victim of the offence was recorded as complainant in 27.1 percent of cases. 14.3 percent of the summonses were issued by officials, for example, the school attendance officer or the market inspector.

Among the cases that were tried summarily by the magistrates in which the defendant was a female, 88.6 percent resulted in a guilty verdict and 11.4 percent in a not guilty verdict. With regard to the type of offence, regulatory offences had the highest conviction rate at 95 percent and public order offences followed closely with a conviction rate of 94 percent. Property offences had a conviction rate of 75.8 percent and violent offences had the lowest conviction rate at just 62.8 percent. However, there was a direct correlation between the type of offence and who had issued the summons, and the chance of successful prosecution. The police were the most successful in securing a guilty verdict. The police issued nine out of ten public order summonses, particularly those for alcohol-related offences, and in 97 percent of the summonses issued by the police, the defendant was found guilty. Officials were similarly successful, securing a guilty verdict in 93.3 percent of the summonses issued by them. Essentially prosecutions brought by officials or by the police, whether or not acting in a regulatory capacity, were more likely to secure a guilty verdict than those brought by private individuals.

Summonses issued privately were the least successful. The bench returned a not guilty verdict in just over a third of summonses issued by the victim of the offence. Nine out of ten of the prosecutions for violent offences and more than eight out of ten for property offences were initiated by the victim, male or female, with equally low conviction rates. From the high conviction rate of cases led by the police it seems evident that Stafford magistrates held the evidence of the police in high regard when considering the guilt of a defendant. Nevertheless, they were prepared to listen to, and accept, the testimony of the defendant. For example, in 1866 the bench cautioned and discharged Sarah Leadbetter, a 'prostitute', who appeared before them for the twenty-sixth time in ten years on another charge of drunkenness. She had pleaded not guilty in this case, claiming that:

she had only come out of prison a month ago, and that the policeman had a grudge against her and had said he would have her again before a month was out. As the defendant did not seem to have stayed in the street for more than a few minutes, the magistrates took a lenient view of the case and dismissed it with $\operatorname{costs}^{30}$.

Women appeared not only as defendants but also as complainants. Women, however, could not join the police force in England and Wales during this period, nor become officials in the form of Market or NSPCC inspectors, for example ${ }^{31}$. Therefore, of

SA, 25 September 1886.

31 There were four summonses brought by the Lady Superintendent of the Staffordshire County Industrial Home For Discharged Female Ex-Prisoners and Friendless Women in Stafford. They have been counted as summonses led by an official. See Turner $(2009$, section 7,6$)$ for a discussion of this institution. 
all the summonses against female defendants in Stafford between 1880 and 1905 a woman was named as the complainant in only 15.4 percent of all cases - but a woman was named as the complainant in just over half of those summonses issued privately. Of these female complainants in private summonses, one in four had appeared as defendants themselves at some point between 1880 and 1905 and just over a third were known to the defendant as a relative or living within the same household, as a neighbour or as an employee ${ }^{32}$. A quarter of these summonses were for property offences, which usually involved a female employee prosecuting her domestic servant for theft. Another quarter were for public order offences, often when one woman accused another for annoying her, using obscene language, or making threats to her in the street.

However, half of the summonses issued by a female complainant were for offences involving violence, usually following a fight when women accused each other of assault. Apart from the cases of attempted suicide, offences involving violence comprised all those cases of common and aggravated assault that arose from neighbourhood and/or family disputes. In these cases there was often a mass of conflicting and low-quality evidence, competing parties with cross-prosecution taking place, and lack of 'independent' evidence from the police. For example, in 1890, Stafford magistrates dealt with a case in which all the named women had previously appeared before them:

Fanny Haywood, living with her mother in Back Walls North, was charged with assaulting Maria Ferneyhough. There was a cross-summons in which Mrs Ferneyhough was alleged to have been the aggressor and to have struck and threatened Fanny Haywood. The case against Haywood was dismissed and Mrs Ferneyhough was fined $2 \mathrm{~s} 6 \mathrm{~d}$ and costs, and ordered to pay the costs of the window she had broken. Fanny Haywood was charged with assaulting Harriet Pattison, another neighbour, in connection with the previous case. It appeared that the neighbourhood had been kept in a state of ferment all last week by disputes between these parties. It was alleged that on Thursday Haywood committed a serious assault upon Mrs Pattison, which had resulted in a partial disablement of the latter, who had to be carried into the court. Haywood was fined 10s and costs. Harriet Pattison was charged with using threats to Sarah Haywood, mother of Fanny Haywood. This case was dismissed, as was also a case in which Kate Concar was charged with assaulting Maria Ferneyhough ${ }^{33}$.

Of all the prosecutions, cases in which both the complainant and the defendant were female were the least successful in securing a guilty verdict. Those that did succeed involved women of differing social standing, for example a domestic servant as defendant and her female employer as complainant. Unless female offenders were caught red-handed with stolen goods or the victim of an assault had visible injuries, or the complainant was of a higher social standing, magistrates had to decide whom to believe when faced with women of similar social status presenting contradictory statements. Studies have found that magistrates handed down more convictions and harsher penalties to men involved in 'male' contexts of violence than they did to women involved in 'female' contexts, indicating that magistrates targeted their

\footnotetext{
32 Many more would probably have known the defendant, but these statistics are based on those who definitely had some connection as recorded by the police or press.

33 SA, 21 June 1890.
} 
efforts of civilizing lower-class communities at what they considered 'dangerous masculinities'. This, they argue, demonstrates that magistrates considered assaults committed by women as less important and "seems to reflect a more "dismissive" and perhaps "contemptuous" attitude toward women'. ${ }^{34}$

\section{SENTENCING}

Of the 2,365 women that Stafford magistrates considered guilty, initially over half were fined (53.5 percent), nearly a quarter (23.4 percent) were imprisoned, 17 percent were cautioned, and 6.1 percent were the subject of court orders - that is, orders 'to pay' (the dues owed), or 'to leave the town'. The percentage of women actually going to prison rose to 39.4 percent as some of the women either chose not to pay the fine or were unable to pay the fine or raise the money for sureties when bound over. Single women, whether unmarried or widowed, were most likely to be imprisoned while married women, particularly if they had a husband in work, were most likely to be fined. Stafford magistrates did acknowledge, however, that any financial penalty might be "devolved upon her husband, causing her family to suffer" and occasionally sent married women to prison ${ }^{35}$.

Being convicted of offences relating to prostitution and vagrancy were most likely to lead to a custodial sentence. Not only were the police and magistrates particularly keen to clear the streets of women begging or propositioning men, but to fine them would have been hopeless since they had no money. If they were fined, then it was usually such a prohibitively high fine that they might as well have been sent to prison in the first instance. Theft was most likely to engender a severe custodial sentence, while a breach of regulatory legislation usually led to a fine or court order 'to pay'. However, being convicted of drunkenness was more likely to lead to a fine rather than custody, unless the woman was vagrant, in which case she could be either imprisoned or 'ordered to leave the town' ${ }^{36}$.

For example, in 1887 Mary Johnson, a vagrant woman of Scottish descent who according to the $S A$ was 'A Confirmed Inebriate', appeared before the magistrates for the fourth time. Although, Mary had been summonsed for drunkenness, both the police and prison officers recorded Mary's occupation as 'vagrant' and 'no fixed abode' for her address. Mary was also recorded as a widow with no children and in her early thirties:

Sergt. Price said the defendant was very drunk and shouting in the Friars. The defendant said she was only discharged from prison on Saturday, and she intended to sign the pledge. She complained that the Discharged Prisoner's Aid Society only gave her some bread and cheese and she was too weak to walk back to Dumfries. The mayor said on the $28^{\text {th }}$ November the defendant was sent to prison for a month for drunkenness. On the day of her release she got drunk and was sent for another month. On being released again she got drunk and was again sentenced for another month's imprisonment. The magistrates would give her one more chance. The case would be adjourned till Monday. If she had left the town

\footnotetext{
34 Godfrey et al. (2005, p. 717)

35 SA 24 July 1880.

36 Most, but not all, vagrant women in the dataset were single.
} 
by that time she would be out of the way; if not, she would be sent to prison for another month. The defendant left the court assuring the Mayor, with a Scotch accent, that he was 'a dear mon' ${ }^{37}$.

Mary did not re-appear in Stafford's Petty Sessions. She had obviously moved on but only to Newcastle-under-Lyme, a town thirteen miles to the northwest of Stafford. Newcastle-under-Lyme magistrates committed Mary to Stafford prison for another month for drunkenness on 11 March 1887, just a week later, and then for another month on discharge for 'using obscene language'. Following her discharge from that sentence on the 7 May, Mary either left the area altogether or died (although no death certificate could be found for her) as she was not re-committed to Stafford prison again.

Stafford prison was a local prison and the county prison for Staffordshire. It also took prisoners transferred from other local prisons when capacity allowed and held people awaiting transfer for penal servitude. People who were not local to Stafford were expected to move on after discharge. Many did not. The 'temperance pledge' was a promise to abstain from alcohol and not to provide it to others. The English temperance movement was not particularly concerned with confirmed drunkards, as they were thought to be beyond help from the self-help strategies advocated by temperance followers. Yet, it was dominated by men and concerned largely with male working-class drinking, and therefore not overly concerned with female drinking ${ }^{38}$.

Of those cases where Stafford magistrates sentenced the defendant to custody, over 90 percent received a short sentence of twenty-eight days or fewer with the most likely sentence being fourteen days. It was the women convicted of theft who were most likely to receive a longer custodial sentence of up to six months' imprisonment.

If subject to a financial penalty, nearly three quarters received a small fine of five shillings or less ${ }^{39}$. Stafford magistrates seem to have been conscious of the inability of most female offenders to meet large financial penalties; accordingly very few women were fined an amount more than ten shillings. Only women convicted of theft, nuisance, prostitution, or violence were fined amounts above ten shillings. For example, Jane Peake was 'fined the maximum penalty' of forty shillings for soliciting prostitution in 1904, as she 'had become a public nuisance' 40 . Jane, not surprisingly, could not meet this penalty and so went to prison - for the twenty-seventh time. All those found guilty and fined would, of course, have to pay the courts costs as well which were generally between five and ten shillings. Many women went to prison in default of payment or opted to take the custodial sentence rather than find the money to pay their fine. There was no formal system of payment of fines by instalments or having time to pay; such arrangements were at the discretion of the police - of which one woman in particular fell foul. Mary Ann Roberts, a lodging-house keeper of Irish descent but married to a Stafford born man with whom she had four children,

SA, 5 March 1887. Prior to the inception of the Probation Service in the early twentieth century, many districts had a Discharged Prisoner's Aid Society who provided basic charitable assistance to people leaving prison.

38 Morrison (2005, chapter 2). See also Shiman (1986); Radzinowicz, Hood (1990, p. 288).

39 A 'shilling' was a coin in the pre-decimal monetary system of England that ended in 1971. Five shillings was approximately equivalent to five pence in the current English decimal monetary system. During the research period twenty-five shillings was an average weekly wage for a man and the cost of issuing a summons in the Petty Sessions was just five shillings.

40

SA, 12 March 1904. 
was in court for being drunk and disorderly and common assault and asked for 'time' to pay her fine:

In the course of this case, Inspector Stretton asked the defendant whether he did not find her behind the door of the public house. She immediately replied that she went there because she was afraid of him, he was so ugly; just like Peace the Murderer. The worthy Inspector evidently felt sore at this imputation on his good looks, and when the defendant was found guilty on both charges, asked him for time to pay the fines he at once said he would not give her a minute, and had her taken to the cells there and then. She was liberated later on in the day ${ }^{41}$.

Ultimately, the picture that emerged from the analysis of all female offending was largely one of women committing public order offences, which were successfully prosecuted by the police in the Petty Sessions, and for which the women received small fines or short prison sentences. Although there were nearly three thousand summonses issued against women in Stafford between 1880 and 1905, there were 1,504 different women who appeared as a defendant. Without identifying each of these women, that number must remain indicative ${ }^{42}$. However, from the demographic data collected, it is clear that those women were most likely to be either unemployed or working in a domestic environment and around the age of forty years.

\section{THE DEFENDANTS' OCCUPATION}

The police and prison officials usually recorded the occupation of the female defendants summonsed in Stafford. As many women and men were employed on a day-to-day basis, a given occupation does not necessarily mean that they were actually employed at the time of summons. Rather their occupation was more likely to have been the type of work they would do, if not in employment at the time. However, in those cases where an occupation was recorded, 42.4 percent were more descriptions of lifestyle or social status than 'occupations' and presumably were noted without the defendant being asked ${ }^{43}$. These were the 'prostitutes', 'tramps' and those women whose 'occupation' was given in relation to the head of the household in which they were living (usually a man) - either as 'married', 'widow' or 'single'. Sometimes the police recorded 'wife of.....' or 'widow of...' And then usually the name of a man - but not always. Mary Pearson, who was prosecuted for throwing vitriol, was recorded as being 'the widow of a cheese factory'.

Where a specific occupation was mentioned, three quarters were recorded in employments that were largely performed in the home or as live-in positions. Just over one quarter of the occupations recorded related to self-employment. These included well-defined businesses such as greengrocers, confectioners, and lodging houses but also ill-defined trades such as hawkers, rag and bone gatherers, and pedlars. During

$\overline{41 \quad \text { SA } 27 \text { June } 1889 .}$

42 See Turner (2009, chapter 3) for an explanation of how women were identified. Many women appeared only once or twice in court and were considered 'non-recidivist' women. There were, however, 176 women, responsible for 62.4 percent of the female crime in Stafford, who can be identified with certainty as having previously been convicted by Stafford magistrates at least three times. See Turner (2011) for a discussion of the conviction and punishment of these recidivist offenders.

43 There were 707 cases where no occupation was recorded. 
the period under investigation, all of these trades were live-in positions. Just over one quarter of the occupations included such work as cleaning or washing, denoted by the terms 'laundress' and 'charwoman'. Although some women went out of their home to do these jobs, they were mainly performed in a domestic environment, if not at home. Women often 'took in' laundry to supplement the income of the main wage earner. The last quarter was mainly comprised of occupations given as 'housekeeper' or 'domestic servant', while a few women were recorded as being licensees of public houses. Licensees would, of course, have lived above their public house. Domestic service was changing during this period from a principally live-in position to a day job ${ }^{44}$, so domestic servants could have either been living on the premises where they were employed - particularly those registered as housekeeper - or going out of their home environment to perform the work. This distinction, however, was not made in the records.

Only a quarter of the occupations recorded would have required the woman to leave the house to work. These were almost all factory positions, either in the boot and shoe trade (Stafford's main industry) or another type of factory ${ }^{45}$. No detailed figures are available to indicate the proportion of women's participation in the labour force in Stafford and its surrounding areas. However, the footwear and pottery industries were major employers of the relatively cheap workforce that women and children provided during this period, and the female occupations listed in the records used for this research appear to be representative of Stafford women's employment as a whole.

None of the women recorded as factory workers were prosecuted for a work related offence. Petty offending of this nature was probably dealt with in-house ${ }^{46}$. One exception were two very minor cases involving two young girls. In 1883 fourteen-year-old Emma Atkins was cautioned and discharged for 'absenting herself from her service and neglecting her employment'. She "admitted being absent as stated. She was kept at home by her father to assist in the house, and with regard to the neglect of work it appeared that she had to close about 12 dozen slams between 2 and 6.30 o'clock, and only did 2 and a half dozen" ${ }^{47}$. Fifteen-year-old Rebecca Evans was ordered to pay her employers one shilling in damages for 'neglect of service'. Due to her nervousness: "her father appeared in court on her behalf as it was on his advice she left the job, not realizing that notice should have been worked"48. Both girls were employed in a shoe factory and neither had any subsequent summonses. In only twenty-nine cases was the occupation recorded as being, for example, a musician, actress, or boatwoman, and only in just three cases was the occupation a semi-professional position - one female defendant was a teacher, who was convicted of 'obtaining food and lodgings by false pretences', and two were nurses, who were both convicted of drunkenness.

\footnotetext{
44 Gleadle (2001, p. 110).

45 As Stafford is close to the Potteries (namely Stoke-on-Trent) many of these women indicated 'pottery worker' as their occupation.

46 For a discussion of workplace policing see Godfrey (1999).

47 SA, 13 October 1883.

$48 \quad S A, 5$ March 1887.
} 


\section{THE AGE OF DEFENDANTS}

Although gender has come to the forefront in criminological and historical research in the last thirty years, age as a variable has seldom been integrated into studies of the operation of the criminal code ${ }^{49}$. Where it is, recent criminological studies stress the youth of the majority of people who find themselves in court. However, in the few historical studies that have considered age as a factor a different picture emerges, specifically where women are concerned. Godfrey puts the peak age for violent offences for women between thirty and forty-years-old in the early twentieth century (the closest approximation to the findings of this analysis) and King found that the peak age of property offences for women was between nineteen and twenty-one years in 1791 and twenty-two and twenty-three years by $1821^{50}$. King also demonstrated that there were various points in the life-cycle - such as single adulthood, the years of child rearing, and widowhood - when women were particularly vulnerable economically, a vulnerability that often resulted in offending behaviour.

Table 2 shows that, taking the individual ages of the female defendants as discrete entities, the age at which women in Stafford were most likely to be summonsed for any offence was forty-years-old ${ }^{51}$. The modal age of defendants, at forty years, was very closely correlated to the mean and median ages ${ }^{52}$. The age range was seventyfive years; the youngest female summonsed was ten-years-old (minimum value) and the oldest eighty-five-years-old (maximum value).

Table 2. Central Tendency of the Age of Defendants ${ }^{53}$

\begin{tabular}{|l|l|l|l|l|l|l|l|}
\hline Valid & Missing & Mean & Median & Mode & Range & Minimum & Maximum \\
\hline 2715 & 154 & 38.23 & 38 & $\mathbf{4 0}$ & 75 & 10 & 85 \\
\hline
\end{tabular}

There were two ten-year-old girls summonsed. The first was bound over for six months in First Offenders Act for 'stealing $40 \mathrm{lbs}$ of potatoes' from the County Asylum in 1902. She was not, however, on her own. Lily was caught red-handed along with two other female co-defendants, both girls (aged eleven and thirteen years), who were similarly bound over. Stafford magistrates had dealt leniently with the case, although "PC Foden caught the children in the act", "Dr Bufton, clerk at the County Asylum, said that as the defendants pleaded guilty, they did not wish to press the case" ${ }^{54}$. In 1899 another ten-year-old girl, Beatrice Key, was remanded to the workhouse, Stafford Union, which was regularly used by the magistrates to

\footnotetext{
49 With the notable exceptions of King (1996); Godfrey (2004).

50 Godfrey (2004); King (1996).

51 For this research, the age of the defendant was taken as recorded by the police, court or prison officials.

52 The mode is the value that occurs most frequently in the age distribution; the mean is the average value; and the median the value at the mid-point of the range. The close proximity of each of these values demonstrates that the sample size of the research was adequate for its statistical purpose.

53 There were 154 of the 2,869 summonses in which the age of the defendant was not recorded. These 154 cases are not taken into account by SPSS when calculating the central tendency of variables hence a 'valid' figure of 2,715 rather than 2,869 .

54 SA, 18 October 1902.
} 
hold people on remand, particularly in cases where previously the defendant had not been to prison. Thereafter she was to be "sent to an industrial school until sixteenyears-old", for "obtaining $3 \mathrm{~s}$ in money by false pretences from George Austin [the cemetery registrar]." Beatrice apparently "went to Mr Austin and said she had been sent by Mrs Key, her aunt, of Cope's Buildings, to borrow 3s". Beatrice was dealt more harshly than Lily as "the magistrate's clerk said there were a number of similar cases in which the girl was concerned" ${ }^{15}$. For both girls it was their only appearance before Stafford magistrates.

The oldest woman summonsed was an eighty-five-year-old widow who was summonsed for non-payment of the Poor Rate in 1893. This woman had four convictions between 1880 and 1905 for non-payment of the Poor Rate after she was widowed, the last being when she was aged eighty-five years. This was despite having run a successful greengrocers business in Stafford with her husband for at least thirty years and keeping a servant after being widowed. For the last summons, Stafford magistrates issued a distress warrant and, at that point, she probably went to live with one of her four children as she was not admitted to the workhouse and died four years later without being summonsed again.

Chart 2 shows that, when the ages of the female defendants were split into bands, 42.2 percent of the female defendants were aged between thirty-one and forty-five years and over a quarter were aged forty-five years and over. At each end of the spectrum, figures were much lower. Only 2.5 percent of the female defendants were aged sixteen years and younger and 0.6 percent aged seventy-six-years and older.

Chart 2. Age distribution in bands.

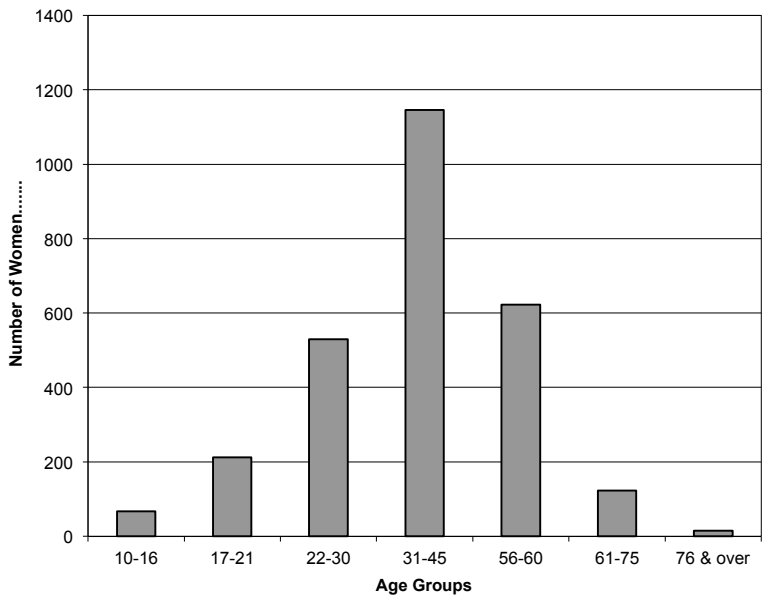

The prevalence of juvenile criminality, and the subsequent treatment of juveniles by the criminal justice system, during the nineteenth century have been

5 SA, 24 June 1899. 
extensively documented in several wide-ranging analyses ${ }^{56}$. However, by the turn of the twentieth century, as Cox makes very clear, girls were generally regulated through welfare rather than criminal justice mechanisms, and when they were tried for criminal offences they were mainly dealt with for theft $\mathrm{t}^{57}$. Girls in Stafford aged between ten and sixteen years were most likely to be prosecuted for property offences, specifically stealing from employers, if they were employed as domestic servants, 'picking pockets' or 'stealing from the person'.

There were only two girls, both domestic servants, who were charged and then cautioned for attempted to commit suicide, and six girls summonsed for assault, all of whom were summonses issued privately and subsequently dismissed by Stafford magistrates. There was no evidence of these girls being involved in youth gang related incidents in Stafford. Three girls were summonsed for vagrancy, all of whom were cautioned by the magistrates, and just one girl prosecuted for a prostitution offence. Fifteen-year-old Alice Hood was imprisoned for fourteen days for 'soliciting prostitution' in Martin Street ${ }^{58}$. A month later, her mother was sentenced to one months' imprisonment for 'keeping a brothel'. Neither Alice nor her mother had any subsequent summonses during the period under investigation, although both continued to live in Stafford. The only juvenile offender who went on to offend as an adult was Sarah Rowe. Having been raised in Aston Workhouse, Sarah first appeared in Stafford aged sixteen years when she was cautioned and discharged for drunkenness. She went on to have fourteen committals to Stafford prison all for public order offences, such as drunkenness, prostitution and 'being a rogue', before dying in Stafford at the age of twenty-three.

Thus, all the juvenile female offending in Stafford was trivial and dealt with by the magistrates; none of the cases was committed to a higher court. In fact, Stafford magistrates dismissed nearly a quarter of the summonses against girls. They even allowed a case to be withdrawn because the defendant was young. Louisa Cotton was just twelve years old when she was caught in the act of "stealing a cash box and 2 purses" from Elizabeth Dean's shop. In court, Mrs. Dean "asked that the case might be withdrawn on account of the tender years of the accused, and to this the magistrates consented" 59 . If found guilty, girls were usually cautioned or lightly punished. Only ten cases resulted in imprisonment, and these all followed a conviction for theft. Otherwise the girls were, like women, most likely to receive a small financial penalty - in a third of the cases that resulted in a conviction the magistrates imposed a financial penalty - and all found the means to meet that penalty. Although there was evidence in many cases of family history of criminality, or family involvement in the incident, only five girls went on to have subsequent appearances before Stafford magistrates.

Female offending in Stafford was largely a matter for the Petty Sessions, and even then the number of women coming before Stafford magistrates was decreasing

$56 \quad$ See for example Gillis (1975); Humphries (1981); Hendrick (1990); Mahood, Littlewood (1994); Shore (1999); Cox, Shore (2002). See Cox (2003) and Cale (1993) for a discussion of the treatment of young girls in institutions during this period.

57 Cox (2003, p. 15).

58 This case occurred in 1887, two years after the age of consent had risen from thirteen to sixteen years of age.

59 SA, 21 August 1897. 
across the majority of offence categories, particularly for public order offences. Summonses for alcohol-related offences, in particular, plummeted and the low number that remained became concentrated on a minority of 'habitual drunkards'. The only rise in summonses, albeit a small one, was when women breached the increasing regulatory legislation. However, this is not to say that women were committing fewer and fewer offences or drinking less - whether they did or not remains unknowable. It does seem, however, that women's involvement in crime became less of a concern, except when they broke the increasing number of restrictions imposed to regulate previously unregulated aspects of private and public life and behaviour. For example, the impact of the NSPCC in assessing women's and men's ability to care for their children was proportionally substantial.

Unlike other studies of female offending, the research on which this article rests was able to collect a near complete set of data relating to the demographics of the female offending population of Stafford. In historical research, the age of women summonsed is particularly lacking. Contrary to statistics on female offending more than a century later, the research in Stafford revealed a low number of juvenile female offenders. Between 1880 and 1905, there were only sixty-seven summonses in Stafford of girls aged sixteen years or below. The largest proportion of the summonses issued against girls was cases in which a domestic servant was accused of theft. This is interesting given the historical interest in juvenile offending, its increase throughout the nineteenth century as well as the contemporary rise of the 'ladette'. The limited number of prosecutions against young women in Stafford may have been due to police officers not taking girl offenders particularly seriously or being reluctant to criminalise women so young; preferring instead to deal with their misdemeanours informally. Police officers may also have felt that confronting and arresting girls reflected on their own masculinity.

However, the records also reveal a large proportion of 'middle-aged' women being summonsed for 'rough', unfeminine behaviour such as drunkenness, using obscene language or insulting words, and common assault. Even women at an advanced age were being summonsed, mainly for drunkenness, and if convicted, sent to prison. There were very few summonses of women for overtly gendered crime such as prostitution although when such incidents arose, the conviction rate was high and the sentence usually custodial. Those women considered by the police to be 'prostitutes' were most commonly prosecuted for unwomanly behaviour such as drunkenness, similarly to other 'rough' women, rather than for prostitution. Again, this is particularly interesting given the manner in which so much of the recent history of criminal women has focussed on the prostitute. The absence of prosecutions for prostitution in Stafford may indicate that prostitution ceased to be much of a concern for the police unless women were unashamedly contravening decency standards or were visible on the streets of Stafford.

Much of what has been known about female petty offenders at the turn of the twentieth century has been anecdotal and a number of the findings from the research in Stafford may appear obvious. However, this article now provides a significant evidential under-pinning for many suppositions that are made. Whether the findings of this research are applicable beyond its own parameters remains a question for further empirical research. However, it has been demonstrated that female petty offenders in Stafford during the late nineteenth and early twentieth centuries were not 'bad'; as there was very little actual criminal offending. These women were generally suffering from the effects of poverty and often living in a culture of petty 
offending and alcohol (mis)use. They were not being prosecuted because they were women, but for being alcohol-dependent, poor, destitute, and, sometimes, feisty. Unfortunately for the women of this research, the non-existence of social welfare policies accompanied an indifferent penal system. Stafford magistrates did have an institution at their disposal specifically designed for the reform of female offenders, but there is no evidence that they referred any of the recidivists to it. Nor do we observe in Stafford the large-scale shift in the practice of committing drunken women to reformatories, as Morrison highlighted. Instead the magistrates continued to impose small financial penalties and short terms of imprisonment, after which women were generally free to offend again. Merely returning the women to their pre-offending environment did little to alter their lives in a significant way. Some of these women belonged to the 'labouring poor', although many more of them belonged to the even less articulate minority who, by definition, left few records for historians to study. For this reason, many historians have avoided engagement with the full range of offending by women. This article has gone some way to rectify that situation.

Joanne Turner

30 Marsh Avenue

ST5 8BB

joanne.turner2@btinternet.com30

\section{REFERENCES}

Arnot, M., Gender in Focus: Infanticide in England 1840-1880, Unpublished PhD thesis, University of Essex, 1994a.

Arnot, M., Infant death, childcare and the state: the baby-farming scandal and the first Infant Life Protection legislation of 1872, Continuity and Change, 1994b, 9, pp. 271-311.

Ballinger, A., Dead Woman Walking: Executed Women in England and Wales 1900-1955, Aldershot, Ashgate, 2000.

Bartley, P., Prostitution: Prevention and Reform in England, 1860-1914, London, Routledge, 2000.

Behlmer, G. K., Deadly Motherhood: Infanticide and Medical Opinion in Mid-Victorian England, Journal of the History of Medicine and Allied Sciences, 1979, 34, pp. 403-427.

Behlmer, G., Child Abuse and Moral Reform in England 1870-1908, California, Stanford University Press, 1982.

Cale, M., Girls and the Perception of Sexual Danger in the Victorian Reformatory System, History, 1993, 78, pp. 201-217.

Conley, C., The Unwritten Law: Criminal Justice in Victorian Kent 1850-1880, Oxford, Oxford University Press, 1991.

Cox, P., Gender, Justice and Welfare: Bad Girls in Britain, 1900-1950, Basingstoke, Palgrave Macmillan, 2003.

Cox, P., Shore, H. (Eds), Becoming Delinquent; British and European Youth, 1650-1950, Aldershot, Ashgate, 2002.

D'Cruze, S., Everyday Violence in Britain, 1850-1950, London, Longman, 2000.

D'Cruze, S., Jackson, L., Women, Crime and Justice in England since 1660, Basingstoke, Palgrave Macmillan, 2009.

Dyhouse, C., Working-Class Mothers in England, 1895-1914, Journal of Social History, 1978,12 , pp. 248-267. 
Emsley, C., Crime and Society in England, 1750-1900, London, Longman, 1996.

Feeley, M., Little, D., The Vanishing Female: The Decline of Women in the Criminal Process, 1687-1912, Law and Society Review, 1991, 25, 4, pp. 719-757.

Finnegan, F. E., Poverty and Prostitution: A Study of Victorian Prostitutes in York, Cambridge, Cambridge University Press, 1979.

Gatrell, V. A. C., The decline of theft and violence in Victorian and Edwardian England, in Gatrell, V. A. C., Leman, B., Parker, G. (Eds), Crime and the Law: The Social History of Crime in Europe since 1500, London, Europa, 1980.

Gillis, J. H., The evolution of delinquency in England 1890-1914, Past and Present, 1975, 67, pp. 96-126.

Gleadle, K., British Women in the Nineteenth Century, London, Palgrave, 2001.

Godfrey, B., Workplace appropriation and the gendering of factory "law": West Yorkshire, 1840-1880, in Arnot, M., Usbourne, C. (Eds), Gender and Crime in Modern Europe, London, UCL Press, 1999, pp. 137-150.

Godfrey, B., Counting and Accounting for the Decline in Non-Lethal Violence in England, Australia, and New Zealand, 1880-1920, British Journal of Criminology, 2003, 43, 2 , pp. 340-353.

Godfrey, B.,"Rough" Girls: The "Recent” History of Violent Young Women, 1900-1930, in Alder, C., Worrall, A. (Eds), Girl's Violence: Myths and Realities, Albany, State University of New York Press, 2004, pp. 21-40.

Godfrey, B. S., Farrall, S., Karstedt, S., Explaining Gendered Sentencing Patterns For Violent Men and Women in the Late-Victorian and Edwardian Period, British Journal of Criminology, 2005, 45, pp. 696-720.

Godfrey, B. S., Farrall, S., Cox, D. J., Criminal Lives: Family Life, Employment, and Offending, Oxford, Oxford University Press, 2007.

Godfrey, B., Changing prosecution practices and their impact on crime figures, 1857-1940, British Journal of Criminology, 2008, 48, pp. 171-189.

Grace, S. Female Criminality in York and Hull 1830-1870, unpublished PhD thesis, University of York, 1998.

Gray, D., The Regulation of Violence in the Metropolis: the Prosecution of Assault in the Summary Courts, 1780-1820, The London Journal, 2007, 32, 1, pp. 75-87.

Grey, D., More ignorant and stupid than wilfully cruel' : homicide trials and 'baby-farming' in England and Wales in the wake of the Children's Act 1908, in Crimes and Misdemeanours: Deviance and the Law in Historical Perspective, 2009, 2, 3, pp. 60-77.

Greenslade, M. W., Johnson, D. A., Currie, C. R. J., The Victoria County History of Staffordshire, volume V1, London, University of London, 1995.

Harrison, J.F.C., Late Victorian Britain, 1875-1901, Glasgow, William Collins Press 1990.

Hendrick, H., Images of Youth. Age, Class and the Male Youth Problem, 1880-1920, Oxford, Clarendon Press, 1990.

Hendrick, H., Child Welfare. England 1872-1989, London, Routledge, 1994.

Higginbotham, A., Sin of the Age: Infanticide and Illegality in Victorian London, Victorian Studies, 1989, 32, pp. 319-337.

Hoffer, P. C., Hull, N. E. H., Murdering Mothers: Infanticide in England and New England, 1558-1803, New York, New York University Press, 1981.

Howell, P., Geographies of Regulation: Policing Prostitution in Nineteenth-Century Britain and the Empire, Cambridge, Cambridge University Press, 2009.

Humphries, S., Hooligans or Rebels? An Oral History of Working-Class Childhood and Youth 1889-1939, Oxford, Blackwell, 1981.

Jackson, L., Child Sexual Abuse in Victorian England, London, Routledge, 2000. 
Jackson, M. (Ed.), Infanticide: Historical Perspectives on Child Murder and Concealment, 1550-2000, Aldershot, Ashgate, 2002.

Kermode, J., Walker, G. (Eds), Women, Crime and the Courts in Early Modern England, London, UCL Press, 1994.

King, P., Female Offenders, Work and Life-Cycle Change in Late-Eighteenth Century London, Continuity and Change, 1996, 11, pp. 61-90.

King, P., Crime and Law in England, 1750-1840: Remaking Justice from the Margins, Cambridge, Cambridge University Press, 2006.

Lewis, J., The Politics of Motherhood: Child and Maternal Welfare in England, 1900-1939, London, Croom Helm, 1980.

MacKay, L., Why They Stole: Women in the Old Bailey, 1779-1789, Journal of Social History, 1999, 32, pp. 623-639.

Mahood, L., Littlewood, B., The "vicious girl" and the "street-corner boy": sexuality and the gendered delinquent in the Scottish child-saving movement 1850-1940, Journal of the History of Sexuality, 1994, 4, pp. 549-578.

Morrison, B. L., Ordering Disorderly Women: Female Drunkenness in England c. 18701920, unpublished $\mathrm{PhD}$ thesis, Keele University, 2005.

Palk, D., Gender, Crime and Judicial Discretion, 1780-1830, Woodbridge, Suffolk, 2006.

Radzinowicz, L., Hood, R., A History of English Criminal Law and its Administration from 1750, volume 5, Oxford, Clarendon Press, 1990.

Rose, L., The Massacre of the Innocents: Infanticide in Britain, 1800-1939, London, Routledge and Kegan, 1986.

Shiman, L., Changes are Dangerous: Women and Temperance in Victorian England, in Malmgreen, G. (Ed.), Religion in the Lives of English Women, 1760-1930, London, Croom Helm, 1986, pp. 193-215.

Shore, H., Artful Dodgers: Youth and Crime in Early Nineteenth-Century London, Woodbridge, Boydell Press, 1999.

Staffordshire Records Office publication, Lasting Impressions. Recollections of the Boot \& Shoe Industry in Stafford, 2007.

Taylor, D., Crime, Policing and Punishment in England, 1750-1914, London, Macmillan, 1998.

Turner, J., Offending Women in Stafford, 1880-1905: Punishment, Reform and Re-integration, unpublished PhD thesis, Keele University, 2009.

Turner, J. Punishing Women, 1880-1905, Howard Journal of Criminal Justice (special issue 'Historical Perspectives on Punishment and Prisons : representations and realities'), 2011, 50, 5, pp. 505-515.

Walkowitz, J., The Making of an Outcast Group: Prostitutes and Working Women in Nineteenth Century Plymouth and Southampton, in Vicinus, M. (Ed.), A Widening Sphere, Bloomington, Indiana University Press, 1977, pp. 72-93.

Walkowitz, J., Prostitution and Victorian Society: Women, Class and the State, Cambridge, Cambridge University Press, 1980.

Waller, P. J., Town, City and Nation: England 1850-1914, Oxford, Oxford University Press, 1991.

Ward, T., The Sad Subject of Infanticide: Law, Medicine and Child Murder, 1860-1938, Social and Legal Studies, 1999, 8, 2, pp. 163-179.

Whitlock, T., Crime, Gender, and Consumer Culture in Nineteenth Century England, Aldershot, Ashgate, 2005.

Zedner, L., Women, Crime and Custody in Victorian England, Oxford, Clarendon Press, 1991. 